\title{
ADMIRALTY SAILING DIRECTIONS AS A GENRE OF ENGLISH MARITIME DISCOURSE
}

\author{
Nataliya Primina ${ }^{1}$
}

\begin{abstract}
The article provides the results of a linguistic analysis of the English maritime discourse. It aims at: defining the essence of the notion "maritime discourse" as a special form of interaction which is carried out in the marine community; analyzing the professional maritime English language as the common international language for communicating at sea; examining compositional, lexical and stylistic peculiarities of the English admiralty sailing directions as a genre of maritime discourse. The work discusses the existing definitions of the notion "maritime discourse" and gives the author's opinion on the issue. The maritime discourse is determined as a communicative activity of the maritime community within professional situations related to different working circumstances at sea, which is realized through verbal means and non-verbal sea codes and the success of which is influenced by various extra-linguistic factors contributing to the fulfillment of professional duties on board the ship. Admiralty sailing directions (pilots) as a genre of maritime discourse are analyzed in the article. They provide essential information to support port entry and coastal navigation for all classes of ships at sea and offer information on navigational hazards, buoyage, pilotage, regulations, general notes on countries, port facilities, seasonal currents, ice and climatic conditions. The compositional structure of the English pilots is investigated and the main compositional parts (Preface; Regular Admiralty Notices to Mariners; Acknowledged signs/signals; Reference List; Conversion Tables; Abbreviations; Scheme of the definite area with its navigation-geographic description) are singled out. The analysis of the maritime language is presented in the article, lexical and stylistic peculiarities common to all pilots are brought to light. The general characteristics inherent to all sailing directions are highlighted: logic; objectivity; accuracy, abstraction; saturation with actual information, explicit presentation of information; neutral emotionality; clarity of presentation.
\end{abstract}

\section{Keywords}

Maritime discourse, English maritime discourse, admiralty sailing directions, composition, lexical and stylistic peculiarities.

1. Introduction. Marine communication is a special form of interaction which is carried out in the marine community connecting people, sea organizations, vessels, marine systems with one goal and one outcome - sea mission accomplished. The English language is considered the common international language for communicating at sea, recommended for use by the International Maritime Organisation (IMO) because "communication in English takes place incessantly in all ports, straits, fairways, waterways, or sea routes of the world between and among speakers who are almost ninety-percent non-native speakers of English"2.

In this regard, the maritime companies require confident knowledge of the general and professional maritime English for all crew members and the heads of the key coastal units - especially in matters of ensuring safe practices in the operation of ships. The seafarers should have the ability to conduct not only external talks in English, but also communicate with other people aboard the ship on basic safety issues, to read marine documentation, instructions, marine catalogues, to understand navigational and reference charts ${ }^{3}$. In order to organize properly such

\footnotetext{
${ }^{1}$ Cand. of Sc. in Philology, National University Odessa Maritime Academy, Didrikhsona Str, 8, 65029-Odessa, Ukraine, Email: primina_natalie@rambler.ru.

ORCID ID 0000-0001-9224-6945

${ }^{2}$ Pritchard 2003, 153

${ }^{3}$ International Convention on the Training and Certification of Seafarers 1978

${ }^{4}$ Bodnar 2014, 132
}

foreign language discursive activity that will unite the participants of different nations and not create cultural barriers for them, it is necessary, states S. Bodnar, to focus attention on learning the typological features of the certain genre of discourse, on mastering verbal and nonverbal means of communication and knowledge of their functions in speech in accordance with the norms and rules of the communicative culture of the certain community ${ }^{4}$. That's why the current research is devoted to the analysis of the definite discourse, namely the English maritime discourse and its linguistic peculiarities.

The object of the given article is the English maritime discourse. The subject is admiralty sailing directions as a genre of the English maritime discourse. The purpose of the research includes the following items: to define the essence of the notion "maritime discourse", to examine the composition of the admiralty sailing directions as a genre of the English maritime discourse, to conduct the analysis of the linguistic features of different levels of the language of the admiralty sailing directions.

Background and motivations. The main features of marine communication have been investigated and presented in many scholarly papers. B. Johnson (1995) examined the features of maritime telex service communication; B. Pritchard \& D. Kalogjera (2000), M. Shishlo (2002) - the features of conversation in maritime VHF communication. I. Olaru (1996) analyzed the style of the seafaring language in general. C. Cole (2001) composed the thematic networks of maritime vocabulary. J. Díaz Pérez 
(2002), P. Trenkner (2005), V. Short (2006) learned the IMO standard marine communication phrases. A. Bocanegra Valle (2010) investigated the maritime communication through radiotelephony. N. Sergeeva (2013) described the most frequent intercultural and communicative marine speech situations. A. Shalov (2015) scrutinized the intonation of marine discourse. O.Tyron (2016) researched the development of foreign language competence of future sailors. However, the comprehensive study of the English maritime discourse and especially admiralty sailing directions as a genre of English maritime discourse remained beyond the scope of the scholars' attention. That brought us to the study of this problem.

2. 2.1. Research materials. To carry out our research, we used the language material selected from current Admiralty Sailing Directions (Australia Pilot) (2016) and Admiralty Sailing Directions (Mediterranean Pilot) (2014). The overall number of sailing directions (pilots) is 30 , or about 180 pages. Each pilot takes 4-7 pages. The lexical units under analysis are 4500 taken from seven typical thematic blocks of sailing directions: "Lights"; "Buoys and signs"; "Dangers"; "Anchorages"; "Inflows and currents"; "Guide to Port Entry"; "Port Rules". The non-verbal messages which accompany the verbal information in the texts of the sailing directions under analysis are 120.

2.2. Methods of analysis. The purpose of this article was reached through the following scientific methods. To present the diversity of current opinions as to the notion "maritime discourse" under analysis, all available literature on the subject was scrutinised. The descriptive and normative-stylistic methods were used to reveal compositional, lexical and stylistic peculiarities of the admiralty sailing directions. The content analysis and generalisation were conducted to define the common features characteristic of the English sailing directions. The quantitative analysis proved the obtained results and enabled us to make objective conclusions.

3. Results and Discussion. First of all there is a need to consider the concept "English maritime discourse" in detail. The English maritime discourse is considered as an instrument for providing communication in the international maritime community that ensures the safety of navigation and contributes to the comprehensive development of the maritime field ${ }^{5}$.

B. Pritchard and D. Kalogjera $(2000,185)$ define English maritime communication as a specific, narrow-scope realisation of the use of the English language characterised by "a limited vocabulary and simple grammatical structure to suit the specific requirements of interpersonal communication and interaction".

\footnotetext{
${ }^{5}$ Trenkner 2005, 21

${ }^{6}$ Admiralty Sailing Directions, 2018
}

The distinctive features of marine discourse according to the words of $\mathrm{O}$. Tyron $(2016,56)$ are the following: 1) marine discourse refers to a certain marine community (it is used in the process of navigation; in the situations of two vessels overtaking each other in the congested waters; in giving requests for mooring and other sea operations; 2) it involves the participation of the representatives of the ship or coastal communities; 3 ) it is used in the situations of communication related to different working circumstances at sea, when various factors influence the success of communication (when receiving or sending radiotelephony messages, interaction in a wheelhouse, etc.); 4) it is used and formed in certain sociolinguistic circumstances (specific interaction between the listener and the speaker in providing the telephone conversations, which are often carried out under stress or even panic).

As for our definition, the maritime discourse is determined as a communicative activity of the maritime community within professional situations related to different working circumstances at sea, which is realized through verbal means and non-verbal sea codes and the success of which is influenced by various extra-linguistic factors contributing to the fulfillment of professional duties on board the ship.

Within this work we are analysing such genre of marine discourse as admiralty sailing directions (pilots) which provide essential information to support port entry and coastal navigation for all classes of ships at sea and offer information on navigational hazards, buoyage, pilotage, regulations, general notes on countries, port facilities, seasonal currents, ice and climatic conditions. This information helps the navigators to increase situational awareness on the bridge ${ }^{6}$. Sailing Directions are compiled in English by global hydrographic services and give the full navigational characteristics of the water area with all its features. Although the authentic Sailing Directions for each region are different in content, they are similar in their compositional structure, vocabulary, grammar constructions and stylistic devices. In this aspect there is a need to consider them in detail.

In our work we have analysed the corpus of data comprising 30 sailing directions taking into account the compositional, lexical and stylistic points of view.

As for the composition of sailing directions we can state that all their parts are placed in a strict order that keeps its regularity in all volumes of sailing directions. Every admiralty guide starts with the following items: Preface; Regular Admiralty Notices to Mariners with the request to inform the Hydrographic service about any up-to-date changes with the latest safety critical information; General Remarks with the information about the acknowledged signs and signals; Reference List; Conversion Tables; Abbreviations. They are followed by the scheme of the definite area with its description which includes the naviga- 
tion-geographic and hydrometeorological outlines of the area, as well as the navigation rules.

The main section of every admiralty guide is the "Navigation description" of the coast which includes: directions for entering the habour, general information about the habour, basins and berths, anchorage, arrival information, port services, off-shore facilities. At the end of every admiralty guide the Glossary, the Index-Gazetteer and Supplements are placed.

It is necessary to note that every sailing direction contains non-verbal information which helps the bridgecrews understand better critical information during the passage planning stage, support safe and compliant navigation within main commercial shipping routes and ports, visualize the coastlines. After analyzing the non-verbal means we have pointed out the most frequent ones: diagrams, tables, charts, schemes, graphs, photos, pictures, drawings, sheets, symbols, framework which occupy about $30 \%$ of the text.

The substantive content of every sailing direction is divided into seven thematic blocks: "Lights"; "Buoys and signs"; "Dangers"; "Anchorages"; "Inflows and currents"; "Guide to Port Entry"; "Port Rules". There is a need to consider each of them in detail.

The first thematic block of the sailing direction is "Lights". It contains information about the lights as a means of navigation and navigation equipment; describes the types of lights, their characteristics and values, location and coordinates; indicates the constructions on which they are displaced, their height above sea level, the range of visibility, as well as the bearings of the luminous lights on the marked coastal landmarks. After conducting the lexical analysis of the topic "Lights" we have found out 55 key words which were met in every sailing direction. For example, light (alternating, fixed, flashing, front, group-flashing, group-occulting, leading, masthead, navigation, occulting, rear, revolving, riding, stern, unwatched); structures (base, column, dwelling, hut, lattice work, lighthouse, light-ship, light-vessel, mast, framework, pile, pillar, pole, post, staff, structure, flat-roofed structure, truncated structure, tower), materials (brick, concrete, iron, steel, stone, wood, wooden), shapes (angle, circular, hexagonal, octagonal, pyramidal, quadrangular, rectangular, square, triangular), eclipse, elevation, exhibit, flash, height, lantern, obscure, show, visibility.

The second thematic block of the sailing directions is "Buoys and signs". It contains information about surrounding the territory by buoys; describes the location of buoys, their shape and colour, top figures and lights they show; provides information about the significance of each buoy in the described water area. Analysing this topic vocabulary we have found out 30 key words for its expressing.

The topic "Dangers" contains information about the dangers of the described coastal zone; indicates the depth and the approximate location of hazards; describes the main characteristics of hazards, such as: washable or dry rocks, close and remote shallows, reefs. Analysing this topic vocabulary we have selected 30 key words which are used in every sailing direction.

The topic "Anchorages" contains information about the recommended anchor points; describes the type of ground, the depth of anchorages and their protection against adverse weather conditions; provides information about the presence of significant coastal landmarks. Analysing this topic vocabulary we have singled out 40 key words.

The topic "Inflows and currents" contains information about the directions of the currents and their speed; describes the time of full and small water and the amplitude of the tide; contains information about the presence of such phenomena as: nestrins, whirlpools, stagnant water. Analysing this topic vocabulary we have selected 25 key words.

The topic "Guide to Port Entry" indicates the recommended course of the vessels passage; contains information about the well-marked coastal landmarks, the presence of buoys and other navigational aids; defines the conditions under which the vessel must sail, such as: the influence of wind, tidal and constant currents, weather conditions and sea conditions. Analysing this topic vocabulary we have selected 20 key words.

The topic "Port rules" sets out the requirements for the ships to enter, leave or stay in the port; describes the signals in this port and the special customs conditions; contains information about the rules of the crew disembarkation in the port. Analyzing this topic, we have found out 20 key words.

The conducted linguistic analysis of all these topics of the sailing directions has shown the following lexical peculiarities:

- the vocabulary is lack of ambiguity and expressiveness; it is characterized mainly by stylistic neutrality, precision and concreteness;

- a great number of specialized terminology (alternating light, truncated structure, bank, depression, province);

- maritime terms that have full correlation with the native language (absolute equivalence) (ballast, keel, water line, mole, piers);

- terms that are similar in the way of expressing with the native language, but different in the meaning, so-called pseudo-equivalents, for example: the word "evolution" but in the marine context it means "maneuver"; the word "garage" but in the marine context it means "extended channel section";

- inter-branch terms (model, operation, information, data);

- terminological set phrases (a flashing light, a group-occulting light);

- professional idioms (Clear the decks, Be in the doldrums, Sail close to the wind); 
- international words denoting the concepts of navigation (acclimatization, convention, navigation);

- derivative and complex words consisting of known components (athwartships, lighthouse, headland);

- converted words (sail - to sail, board - to board, blast - to blast, mark - to mark);

- sea abbreviations (ATA - Actual Time of Arrival, ATD - Actual Time of Departure, POD - Port of Destination, EC - East Coast) and acronyms (3DNC three-dimensional digital navigational chart);

- words with no direct equivalents in other languages (a channel pilot - a pilot for ships maneuvering in the English Channel; a blueback - Admiralty English sea chart with a blue back side);

- foreign language borrowings (a number of borrowings from the Latin language: portus $\rightarrow$ port; millia passuum $\rightarrow$ mile (7420 meters));

- digital data that present marine information (Let the observed altitude of the Sun's lower limb, taken in the month of February, be $12^{\circ} 32^{\prime} 15^{\prime \prime}$, and the height of the eye 14 feet), (Chiesa di Santa Caterina $38007^{\prime} 42 \mathrm{~N} 15^{\circ} 39^{\prime} 25 \mathrm{E}$ ).

Studying the stylistic peculiarities of the sailing directions we have marked the following ones:

- presence of stable metaphors (e.g. buoys are moored at turning points, The best anchorage berth is about 1 1/2 cables SE of the head of a small mole; a sunken rock lying to the west of an excellent anchorage);

- epithets (e.g. On very rare occasions an exceptionally strong and powerful current has been experienced during calm weather; Islas Chatarina Lighthouse stands near Torre de la Conquista, which has a prominent clock);

- metonomy (e.g. a navigation head (habour/ port), a deck hand (a seaman);

- comparison (a canal-like entrance to the dock is 75 meters long);

- repetitions (e.g. Keep this mark astern and keep this object in line to proceed to a quarantine anchorage; Bring this flashing light in line with $a$ pillar buoy surmounted by two black cones points down - this pile in line with a pillar buoy leads westward of the underwater ridge to a safe anchorage; Buoys marking the port hand of channels usually exhibit green flashing or white flashing lights);

- parallel constructions (e.g. Care must be taken to avoid a pillar buoy. Care must be taken to avoid the patch).

- detachments (Kamimate Shima, a rocky islet $13 \mathrm{~m}$ high and surmounted by a light-tower, lies 4 cables E of Ugu Shima. Early morning fog, often thick, may be experienced);

- inversion (e.g. In Japanese harbours, light structures marking the entrances to artificial harbours consist of round concrete towers. Off the northern end of the Island the current is usually west-going).
The obtained results indicate that the stylistic devices have their way in the sailing directions but in a limited number of contexts. The most frequent ones are the syntactical stylistic devices $(74 \%)$ : repetitions, parallel constructions, detachments, inversions; the lexical stylistic devices: metaphors, metonymies, epithets, comparisons occupy only $24 \%$ of the text. This tendency shows neutral emotionality of the analyzed documents: influence on the reader is carried out not by means of empathetics, but by the use of arguments, evidence, logic of judgment.

Speaking about the general style of the English admiralty sailing directions we can name the following characteristics: logic (strict sequence, well-grounding, algorithmicity in the formulation of ideas); objectivity (the truth of the given information proven by the definite figures and data, minimization of the subjective position of the author); accuracy (the use of verbalization means that are unambiguous (terms) and express the essence of the concepts accurately), abstraction (no presence of the author's "I" and reader's "I": the author gives the relevant information without subjective evaluation); saturation with actual information, explicit presentation of information; clarity of presentation (simplicity of speech, presentation logic, grammatical clarity).

4. Conclusions. Having analysed a corpus of data comprising 30 sailing directions, we can make a conclusion that they are considered to be a specific kind of maritime discourse which we define as a communicative activity of the maritime community within professional situations related to different working circumstances at sea, which is realized through verbal means and non-verbal sea codes and the success of which is influenced by various extra-linguistic factors contributing to the fulfillment of professional duties on board the ship.

As for the composition of sailing directions they consist of: introductory part (preface; regular admiralty notices to mariners; general remarks; reference list; conversion tables; abbreviations); the main section which is divided into seven thematic blocks: "Lights"; "Buoys and signs"; "Dangers"; "Anchorages"; "Inflows and currents"; "Guide to Port Entry"; "Port Rules"; the final part (the Glossary, he Index-Gazetteer and Supplements).

The detailed review of the linguistic features of the sailing directions has shown a great number of non-verbal means of communication which are placed with the purpose to visualize the verbally-presented information: diagrams, tables, charts, schemes, graphs, photos, pictures, drawings, sheets, symbols, framework. The analysis of the maritime language gave us a chance to state that the English maritime discourse is characterized by a great number of professional terminologies, absence of ambiguity, stylistic neutrality, precision and concreteness. The prospects for further research are in a more detailed analysis of the linguistic features of the other genres of the English maritime discourse. 


\section{BIBLIOGRAPHY}

Боднар С.В. Дискурсивна діяльність в теорії і практиці навчання іноземних мов / С.В.Боднар // International scientific professional periodical journal «The Unity of Science». - 2014. - V. 1. - P. 132-138.

Международная конвенция о подготовке и дипломировании моряков и несении вахты 1978 года (ПДМНВ-78) / отв. исполнитель В.П. Стрелков. - СПб.: ЦНИИМФ, 2010. - 330 с.

Сергеева Н. Н. Методика развития иноязычной межкультурной компетенции будущих судоводителей во внеаудиторной работе / Н. Н. Сергеева // Педагогическое образование в России. - 2013. - № 1. - С. 146-151.

Тирон О. М. Психолого-педагогічні основи формування іншомовної компетентності майбутніх моряків: дис. на здобуття наук. ступеня канд. псих. наук: спец. 19.00.07 «Педагогічна та вікова психологія» / О. М. Тирон. - Київ: відкритий міжнародний університет розвитку людини «Україна», 2016. - 228 с.

Шальов А. С. Інтонаційні особливості морського дискурсу / А. С. Шальов // Науковий вісник Міжнародного гуманітарного університету. Сер.: Філологія. - 2015. - № 16. - С. 198-200.

Шишло М. 3. Обучение будущих судоводителей аудированию в профессиональном радиообмене по УКВ на море : Английский язык, морская академия : дис. на соискание уч. степени канд. пед. наук: спец. 13.00.02 «Теория и методика обучения и воспитания (иностранные языки)» / М. 3. Шишло. - Пятигорск, 2002. - 259 с.

Admiralty Sailing Directions. - Publisher: UK Hydrographic Office. 2018. - Available from:

https://www.admiralty.co.uk/publications/publications-and-reference-guides/admiralty-sailing-directions.

Admiralty Sailing Directions. Australia Pilot. 13th Edition. - Publisher: UK Hydrographic Office. 2016. - Vol. 2. - 100 p.

Admiralty Sailing Directions. Mediterranean Pilot. 15th edition. - Publisher: UK Hydrographic Office. 2014. - Vol. 1. - 115 p.

Bocanegra Valle A. The Language of Seafaring: Standardized Conventions and Discursive Features in Speech Communications / Valle A. Bocanegra // European Journal of English Studies. - 2011. - 11 (1). - P. 35-53. Available from: https://www.researchgate. net/publication/259735026_The_Language_of_Seafaring_Standardized_Conventions_and_Discursive_Features_in_Speech_ Communications [accessed Mar 26 2018].

Cole C. The Thematic Network on Maritime Education, Training and Mobility of Seafarers / C. Cole, P. Trenkner // Eleventh IMLA Workshop on Maritime English (WOME 11). - Varna, Bulgaria, 2001. - P. 35-48.

De la Campa R.M. Communication breakdown / De la Campa R.M. // Marine Engineers Review. - 2003. Dec/Jan. - P. 34-35.

Díaz Pérez J.M. IMO Standard Marine Communication Phrases and teaching their use in the Vessel Traffic Services context / Díaz Pérez J.M. // In Proceedings of the 3rd International Congress on Maritime Innovations and Research. - Bilbao: Universidad del País Vasco. - 2002. - P. 649-658.

Johnson B. Some features of maritime telex service communication. / B. Johnson // English for Specific Purposes. - 1995. 14 (2). - P. 127-136.

Olaru I. The style of the seafaring language, the definite communicative aim of maritime language / I. Olaru // The IMLA Newsletter. - 1996. - N 22. - P. 17-23.

Pritchard B., Kalogjera D. On some features of conversation in maritime VHF communication / B. Pritchard, D. Kalogjera // In M. Coulthard, J. Cotterill \& F. Rock, F. (eds.), Dialogue Analysis VII: Working with Dialogue. - Tübingen: Max Niemeyer Verlag. 2000. - P. 185-196.

Pritchard B. Maritime English syllabus for the modern seafarer: safety-related or comprehensive courses? / B. Pritchard // WMU Journal of Maritime Affairs. - 2003 (a). - 2(2). - P. 149-166.

Short V.A. Maritime English. Valuing a common language / V.A.Short // Seaways, the Journal of the Nautical Institute, supplement to October 2006. - 2006. - P. 1-12.

Trenkner P. The IMO Standard Marine Communication Phrases - Refreshing memories to refresh motivation / P. Trenkner // In Proceedings of the IMLA 17th International Maritime English Conference. France: Marseille. - 2005. - P. 1-17.

\section{REFERENCES}

Admiralty Sailing Directions (2018). Publisher: UK Hydrographic Office.

Admiralty Sailing Directions: Australia Pilot (2016). Publisher: UK Hydrographic Office.

Admiralty Sailing Directions: Mediterranean Pilot (2014). Publisher: UK Hydrographic Office.

Bodnar, S. (2014). Dyskursyvna diyal'nist' u teoriyi ta praktytsi navchannya inozemnykh mov [Дискурсивна діяльність в теорії і практиці навчання іноземних мов]. The Unity of Science 1, pp. 132-138.

Bocanegra, Valle A. (2011). The Language of Seafaring: Standardized Conventions and Discursive Features in Speech Communications. European Journal of English Studies, 11(1), pp. 35-53.

Cole, C. (2001). The Thematic Network on Maritime Education, Training and Mobility of Seafarers. In Proceedings of the Eleventh

IMLA Workshop on Maritime English 2001, (WOME 11), Bulgaria: Varna, pp. 35-48.

De la Campa, R.M. (2003). Communication breakdown. Marine Engineers Review, Dec/Jan, pp. 34-35.

Díaz Pérez, J.M. (2002). IMO Standard Marine Communication Phrases and teaching their use in the Vessel Traffic Services context. In Proceedings of the 3rd International Congress on Maritime Innovations and Research 2002, Bilbao: Universidad del País Vasco, pp. 649-658.

Johnson, B. (1995). Some features of maritime telex service communication. English for Specific Purposes, 14(2), pp. 127-136.

Mezhdunarodnaya konventsiya o podgotovke i diplomirovanii moryakov i nesenii vakhty 1978 [International Convention on the Training and Certification of Seafarers of 1978] (2010). - Saint Petersburg: CNIIMF.

Olaru, I. (1996). The style of the seafaring language, the definite communicative aim of maritime language. The IMLA Newsletter 22, pp. 17-23.

Pritchard, B. \& Kalogjera, D. (2000). On some features of conversation in maritime VHF communication. In M. Coulthard, J. Cotterill \& F. Rock (eds.), Dialogue Analysis VII: Working with Dialogue, Tübingen: Max Niemeyer Verlag, pp. 185-196. 
Pritchard, B. (2003a). Maritime English syllabus for the modern seafarer: safety-related or comprehensive courses? WMU Journal of Maritime Affairs, 2(2), pp. 149-166.

Sergeeva N. (2013). Metodika razvitiya inoyazychnoy mezhkul'turnoy kompetentsii budushchikh sudovoditeley vo vneauditornoy rabote [Методика развития иноязычной межкультурной компетенции будущих судоводителей во внеаудиторной работе]. Pedagogicheskoye obrazovaniye v Rossii [Педагогическое образование в России] 1. pp. 146-151.

Shalov, A.S. (2015). Intonatsiyni osoblyvosti mors'koho dyskursu [Інтонаційні особливості морського дискурсу]. Naukovyу visnyk Mizhnarodnoho humanitarnoho universytetu. Ser.: Filolohiya [Науковий вісник Міжнародного гуманітарного університету. Сер.: Філологія] 16, pp. 198-200.

Shishlo, M. Z. (2002). Obucheniye budushchikh sudovoditeley audirovaniyu v professional'nom radioobmene po UKV na more : Angliyskiy yazyk, morskaya akademiya [Обучение будущих судоводителей аудированию в профессиональном радиообмене по УКВ на море : Английский язык, морская академия]. Dissertation. Department of Methods of teaching. Pyatigorsk State Linguistic University.

Short, V. A. (2006). Maritime English. Valuing a common language. Seaways, the Journal of the Nautical Institute, pp. 1-12.

Trenkner, P. (2005). The IMO Standard Marine Communication Phrases - Refreshing memories to refresh motivation. In Proceedings of the IMLA 17th International Maritime English Conference 2005, France: Marseille, pp. 1-17.

Tyron, О. М. (2016). Psykholoho-pedahohichni osnovy formuvannya inshomivnoyi kompetentnosti maybutnikh moryakiv [Психолого-педагогічні основи формування іншомовної компетентності майбутніх моряків]. Dissertation, Psychology Department, Open International University of Human Development "Ukraine".

\begin{abstract}
Анотація
У статті викладено результати лінгвістичного аналізу англійського морського дискурсу. Метою є: визначення сутності поняття "морський дискурс" як особливої форми взаємодії, що здійснюється в морському співтоваристві; аналіз професійної морської англійської мови як мови міжнародного спілкування на морі; вивчення композиційних, лексичних і стилістичних особливостей англійських лоцій як жанру морського дискурсу. У роботі аналізуються наявні визначення поняття "морський дискурс", і надається авторське трактування цього поняття. Морський дискурс визначається як комунікативна діяльність морської спільноти в межах професійних ситуацій, пов'язаних з різними обставинами роботи в морі, яка реалізується за допомогою вербальних засобів і невербальних кодів морського спрямування і на успішність якої впливають різні екстралінгвістичні чинники, що сприяють виконанню професійних обов'язків на борту судна. Англійські морські лоції як жанр морського дискурсу аналізуються у статті. Лоції надають необхідну інформацію про особливості входу в порт та прибережного плавання для всіх класів суден на морі та інформують про небезпеки для навігацій, буї, лоцманське обслуговування, портові правила, дають загальну інформацію про акваторії, портові споруди, сезонні течії, крижані та кліматичні умови. В роботі проаналізовано композиційну структуру англійських морських лоцій та виокремлено їх основні складові частини (передмова; основні відомості для моряків; загальновизнані знаки та сигнали; довідковий матеріал; морські таблиці; загальновизнані скорочення; опис певного району з навігаційно-географічною інформацією). Особлива увага приділяється невербальним засобам комунікації, які допомагають візуалізувати опис певних морських районів. У статті представлено лексичні та стилістичні особливості англомовних лоцій, наведено приклади їх функціонування. Виокремлено загальні характеристики, властиві всім лоціям: логіка; об'єктивність; точність, абстракція; насиченість фактичною інформацією, докладне представлення інформації; нейтральна емоційність; чіткість презентації.
\end{abstract}

\title{
Ключові слова
}

Морський дискурс, англомовний морський дискурс, лоції, композиція, лексичні і стилістичні особливості. 